\title{
60-72 Aylık Çocukların Canlılık Algısı Üzerine Bir İnceleme: Çocuklar Canlı ve Cansız Varlıklar ile İlgili Ne Düşünüyor?
}

\author{
A Study on Perception of Life of 60-72-Month-Old Children: What Do Children Think About Living and \\ Non-Living Things?
}

\author{
Elif ÖZTÜRK* (D), Meryem TULUM iD
}

\begin{abstract}
öz
Erken yaşlarda doğa ile etkileşimde bulunulması bireyin doğaya karşı farkındalık, bağlılık ve sevgi geliştirmeleri ekolojik sorumlulukların gelişmesine olumlu katkı sağlamaktadır. Fen ve doğa eğitimleri böylece keyifli bir meraka dönüşür. Bu noktadan hareketle, bu çalışmanın amacı beş-altı yaş grubu çocukların canlı ve cansız varlık algılarını ve düşüncelerini incelemektir. Yapılan çalışma nitel bir yaklaşım ile ele alınmıştır. Bu nedenle araştırmada fenomenoloji olgu bilim deseni kullanılmıştır. Dolayısıyla, bu araştırmada beş-altı yaş grubu çocuklarının çevrelerinde yer alan canlı ve cansız varlıklara ilişkin algıları tespit edilmeye çalışılmıştır. Çalışma grubu otuz çocuktan oluşmaktadır. Çalışmada incelenen olgular hakkında derinlemesine veri toplamak amacıyla ölçme aracı olarak "varlık kartları" ve "görüşme formu" kullanılmıştır. Çalışma kapsamında toplanan veriler betimsel analiz ile incelenmiştir. Ayrıca, çocukların canlı ve cansız kavramlara yönelik düşüncelerini belirlemek ve canlı ve cansız nesneler için düşündükleri özellikleri de ortaya çıkarmak hedeflenmiştir. Canlı ve cansız kavramlar ile ilgili çocukların hangi özelliklerine göre bu kavramları canlı ve cansız diye ayırt ettikleri ve bu hususta oluşmuş kavram yanılgıları bu araştırma kapsamında yer almaktadır. Elde edilen bulgulara göre, 'canlılık' kavramı erken çocukluk döneminde bilimsel anlamda yanlış ve eksik olarak öğrenilebilmektedir. Bunun yanında, özellikle çocukların belirgin bir hareketlilik ve gelişim gösteren hayvanların canlılığını daha kolay kavradığı, ancak bitkilerin canlılığı konusunda hareket etmemesi ve gelişimsel farklılıkların gözlemlenmeyişinden ötürü canlı olarak sınıflandırmakta zorluk çektiği belirlenmiştir. Araştırma sonunda araştırmacı ve eğitimcilere uygun öneriler getirilmeye çalışılmıştır.
\end{abstract}

Anahtar Kelimeler: Canlı-cansız varlık algısı, çevre ve doğa eğitimi, erken çocukluk eğitimi

\begin{abstract}
Interacting with nature at an early age contributes to the development of the individual's awareness, commitment, love and development of nature, ecological responsibilities. Science and nature education turns into an enjoyable curiosity. From this point of view, this main purpose is to examine the condition in early childhood of the perceptions of living and non-living beings of children aged five to six. The study has been handled with a qualitative treatment. Therefore, in this study, it was tried to determine the perceptions of children between the ages of five and six regarding living and non-living things in their environment. The study group consists of thirty children. "Cards" and "interview forms" are used as information tools to collect in-depth data on the phenomena examined in the study. The data collected within the scope of the study were analyzed by content analysis, one of the qualitative research methods. In addition, it was aimed to determine the thoughts of children about living and non-living concepts and to reveal the features they think of living and non-living objects. Concerning the concepts of living and non-living, according to which characteristics children distinguish these concepts as living and non-living, and the misconceptions formed in this regard are included in this study. According to the findings, vitality can be learned erroneously and incompletely in childhood. According to the findings obtained, the concept of "vitality" can be learned incorrectly and incompletely in early childhood. In addition, it has been determined that especially children grasp the vitality of animals that show significant mobility and development more easily, but they have difficulty in classifying them as living because they do not act on the vitality of plants and developmental differences are not observed. At the end of the research, suitable suggestions were made for researchers and educators.
\end{abstract}

Keywords: Living-non-living being perception, environmental and nature education, early childhood education 


\section{GİRIŞ}

Eğitimin amacı çocuğa bilgi kazandırmak ve öğrendiği bilgileri yaşamında kullanılır hale getirmektir. Bu durumda fen eğitimi çocuğun yaşam becerilerini geliştirmekte önemli rol oynar; çocuğa kendisini korumayı öğretir, bulunduğu yaşam alanını tanımasına yardımcı olur, tehlikeleri daha çabuk fark etmesini ve hazır bulunuşluk durumu sayesinde problemlere çözüm üretmesini sağlar (Şahin, 2000). Erken çocukluk dönemi, çocukların bilimsel süreç ve becerileri kazandıkları deneyimleri yaşadıkları bir dönemdir. Çocukların bu süreçte yaşadıkları deneyimler, bilgilerin ve kavramların kazanılması için uygun ortam oluşturmaktadır (Kıldan ve Pekşan 2009). Okul öncesi dönem fen alanındaki çevre eğitimleri ilk olarak 1982 yılında Jaus tarafından verilmeye başlanmıştır. Çalışmalara bakıldığında (Halmatov ve Ekin, 2017), çocuklarda çevre faktörüne karşı olumlu tutum geliştirilmesinde erken çocukluk döneminin önem taşıdığı belirtilmektedir. Çevreye olan ilgi bebeklik döneminde meraklı arayışlarla başlarken, üç yaşından itibaren çocukların doğa ile etkileşime geçtiği gözlemlenmiştir. Bu noktada 'formal eğitim destekli çevre eğitimi' olumlu tutum edinilmesinde önemli rol oynamaktadır (Taşkın, 2004).

Çevre, insanların ve diğer canlıların hayatları boyunca ilişkilerini sürdürdükleri ve karşılıklı olarak etkileşim içinde bulundukları ortamdır. Çevre duyarlılığı kazanmış bir çocuk, çevre sorunları karşısında aldığı eğitim desteği ile duyarlı davranarak çözümler üretebilir. Sıfır-altı yaş grubuna verilen formal eğitimde çocuklar doğa ve fen eğitimleri ile tanışırlar. Çocuk merak duygusuyla sorular sorar ve merakını gidermek için araştırmalar yapar (Kesicioğlu ve Alisinanoğlu, 2009). Bu araştırmalar dokunarak, gözlem yaparak ortaya çıkar; fen ve doğa eğitimleri bu yüzden keyifli bir meraka dönüşür (Erbaş, Ergül, Şimşekli ve Özdilek, 2002). Bunun çocuğun etkileşim içerisinde olduğu çevreye karşı tutumlarını da etkilediği görülmektedir (Kesicioğlu ve Alisinanoğlu, 2009). Çevre eğitimi "doğanın dilinin öğrenilmesi” olarak isimlendirilmekte, doğa ile bir arada gerçekleştirilen eğitimle evrene, yaşama ve olaya farklı bakış açısı geliştirildiği belirtilmektedir (Tülin, 2009).

Okul öncesi çocuklarının dikkatini toplaması için nesneler ile ilgilenmeleri gerekir (MEB, 2013). Materyallerin buna yönelik olarak hazırlanması önemlidir, ilgiyi korumak yöntem ve tekniklerle birlikte sağlanır. Fen eğitimi; deney, gezi, gözlem, yansı, haritalar, problem çözme, masa oyuncakları, aktif öğrenme teknikleriyle desteklenir. Günlük olaylar çocukların meraklarını ve ilgisini çekmekte önemli rol oynadığı için buna yönelik etkinliklerle çocukların öğrenmesi amaçlanmaktadır. Çocuklar hem keyifle öğrenir hem de eğlenceli deneyler yapmış olur. Bitki yetiştirmek, yağmur yağdırmak gibi etkinliklerde önemli olan çocuğa uygun materyaller seçerek dikkatleri toplamaktır. Mevsim olayları, hareket olayları, doğadaki devinimsel hareketlilik gibi olaylarda neden sonuç ilişkileri gözlemlendiğinde çocuklar deneyle olayların sıralı oluşumunu daha iyi anlarlar ve birebir tanıklık etmiş olurlar. Araştıran, merak eden, sorgulayıcı kimliğe sahip olan çocuklar oluşur. Buna göre de sorumluluk duygusu gelişir ve çevre duyarlılığı artar (Köşker, 2019). Yaş grubu nedeniyle etkinliklerin ilgi çekici hale getirilmesi çocukların meraklarını gidermesine yardımcı olur. İleriki hayatlarında fene yönelik çalışmalarda keyifle yer alabilirler.

Erken çocukluk döneminde fen konuları ve çevre eğitiminin iç içe olduğu söylenebilir. Bu dönem çevre eğitiminde en çok yer alan kavramlar temelde canlı ve cansız varlıkları barındırmaktadır. Piaget canlı kavramı gelişiminde dört temel unsurun olduğunu belirtir. Birinci olarak üç-yedi yaş arası çocuklarının bir nesneyi canlı olarak düşünmelerine sebep olan basamağın aktivite ve fonksiyonu olmasından kaynaklandığını vurgulamıştır. İkinci basamakta ise yedi-sekiz yaşlarındaki çocukların hareket özelliği olan nesneleri canlı olarak düşündüklerini belirtmiştir. Üçüncü basamakta dokuz-onbir yaş arasındaki çocukların spontane, yani kendiliğinden hareket özelliği kazanmış olan nesneleri canlı olarak düşündüklerini belirtmiştir. Onbir-oniki yaş grubu çocuklarının bitki ve hayvanları canlı varlık olarak düşündüklerini belirtmiştir.

Canlı ve cansız kavramlarını öğrenirken çocuklar bazen yanılgılara düşebilir. Bu, bilginin yanlış aktarılmasından< ya da bireyin zihninde bilgiyi yerleştirme yanlışı̆̆ğından doğmaktadır. Çevre ile etkileşim arttıkça çocuk bilgiyi doğru öğrenmekte ve yeni anlamlar kazandırarak şekillendirmektedir. Canlı ve cansız varlık algılamasında çocuk, tanıdığı nesne hakkında yanılgıya düşebilir (Yeşilyurt, 2003, 85). Bu yanılgıların önlenmesi çocuğun ilk olarak canlılık özelliklerini iyi ve doğru kavrayabilmesine bağlıdır. Bu özellikler canlılığın ortak işlevleri olarak açıklanmaktadır. Buna göre canlılığın ortak özellikleri; beslenme, hareket, solunum, özümleme, büyüme, boşaltım, üreme şeklindedir. 


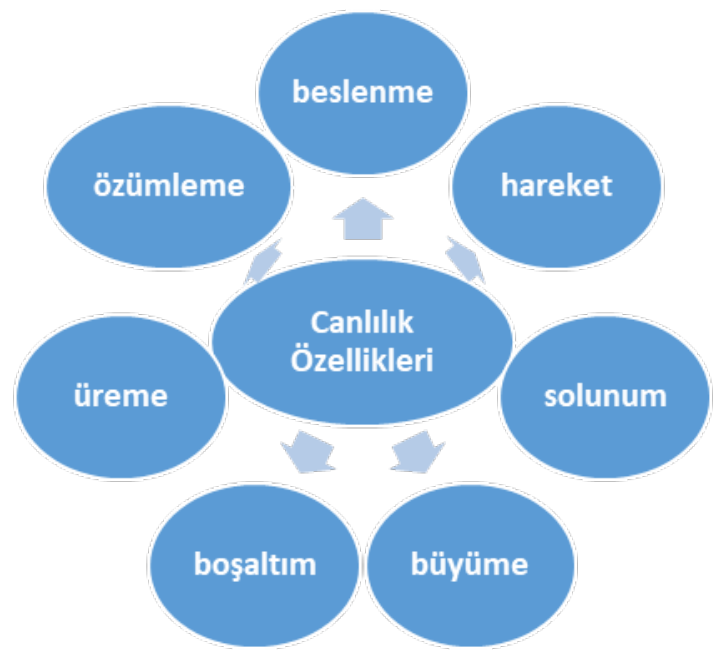

Şekil 1. Canlılık Özellikleri

Canlıları öğrenmeye devam ederken karşımıza çıkacak olan bu özelliklerle ilişki kurulmalıdır. Canlıları birbirine bağlayan temelde birbirine benzer kılan ortak bağ olarak bilinmektedir (Eroğlu, 2003). Canlı ve cansız varlıkların birbiriyle etkileşimi sonucu doğal ve yapay ortamlar oluşmaktadır. Doğal bir çevre insanların müdahalelerinin az olduğu doğal ortamın gelişimini değiştirmedikleri bir ortamdır. Yapay çevre ise insani müdahalelerle inşa edilmiş yapilar ortamıdır (Ertan, 1991; 66-68).

Çevre farkındalığı çocuğa önce aileyle kazandırılmakta ve eğitim ile desteklenmektedir (Çabuk, 2001; 40; Tozlu, 1997; 48-50). Çocuklar gördüğü nesneleri anlamlandırmaya çalışırken sorular sorar ve yorumlar yaparlar. Bu esnada düşünme becerileri gelişir. Ayrıca görsel algı sayesinde sanat gelişimi desteklenir. Çevre her çocuğu farklı kılar. Gelişimsel, bilişsel, fiziksel özelliklerinin farklı olması bundan olduğu düşünülebilir. Gözlemler ve iç dünya arasındaki bağlantı sayesinde yansımalar göze çarpar. Farklı coğrafi özelliklere, sosyal faaliyetlere ve kültüre sahip olan çocuklar mekân ve doğa arasında farklı bir iletişim kurmaktadır. Bu da çocukların çevre, canlı, cansız gibi kavramlar arasında farklı bağlar kurmasına yol açabilmektedir. Çocuklar canlı ve cansız kavramlarını öğrenirken bu sözcükleri okuduklarına veya dinlediklerine göre anlam vermek yerine, daha önce edindikleri bilgileri harekete geçirerek algilama yolunu izlemektedir (Stavy ve Wax 1989).

Çocuklar kavramları öğrenirken dinlediği bilgilere göre anlamlandırmak yerine daha önce duydukları bilgileri esas alarak algılamaya çalışmaktadır (Yeşilyurt, 2003; 85). Canlı nesneler hakkında uluslararası çalışmalar Piaget ile başlayarak diğer uzmanlar tarafından araştırılmaya başlanmıştır. Erken yaşlarda doğa ile etkileşimde bulunulmasının bireyin doğaya karşı farkındalık, bağlılık, sevgi, geliştirmeleri ve ekolojik sorumlulukların gelişmesine olumlu katkı sağladığı bilinmektedir (Ballantyne ve Packer, 2002; Chawla, 2006; Civelek ve Akamca, 2017; Keliher, 1997; Louv, 2010; Özdemir, 2010). Dolayısıyla çocukların hareket algılarının belirlenmesinde doğayla bütünleşik eğitiminin içeriğinin ve sürecinin tasarlanması ve uygulanması çevreye karşı tutumu artıracak ve algılarını güçlendirerek ilginin kalıcı hale gelmesini sağlayacaktır.

Konu ile ilgili alan yazın incelendiğinde özellikle ülkemizde pek fazla çalışmaya rastlanmadığı görülmüştür. Bu noktada çocukların yaşadıkları çevreyi anlamlandırabilmeleri, tanımlayabilmeleri ve yorumlayabilmeleri için bu çalışma gerekli görülmüştür. Bu çalışma, okul öncesindeki beş-altı yaş grubu çocukların canlı ve cansız varlık algılarının okul öncesindeki gelişim durumlarını incelemek amacıyla yapılmışıı. Çocukların canlı ve cansız kavramları hangi özelliklerine göre canlı ve cansız diye ayırt ettikleri bu araştırma kapsamında incelenmektedir. Ayrıca bu çalışmada okul öncesi 5-6 yaş grubu çocukların canlı ve cansız kavramlara yönelik düşüncelerini belirlemek ve canlı ve cansız nesneler için düşündükleri özellikleri ortaya çıkarmak amaçlanmıştır. Bu esnada, çocuklarda bu özellikler hakkında oluşan kavram yanılgıları ele alınmıştır. Çalışmanın araştırma soruları aşağıdaki gibidir;

1. 60-72 aylık çocuklar canlı ve cansız kavramlarını nasıl algılamaktadır?

2. Çocuklar yaşadıkları alanda canlı ve cansız varlıkları nasıl ayırt ederler?

3. Erken çocukluk dönemi çocuklarının cansız varlıkları nitelendirmesindeki kavram yanılgıları nelerdir? 


\section{YÖNTEM}

\section{Araştırma Deseni}

Yapılan çalışma nitel bir yaklaşım ile ele alınmaktadır. Nitel yaklaşımların temel amacı algı ve deneyimlerin ortaya çıkmasını sağlamaktır (Tekindalve Uğuz-Arsu, 2020). Bu tip çalışmalarda yaklaşım bütüncül olarak ele alınır ve birbirleri ile etkileşimleri incelenir. $\mathrm{Bu}$ nedenle bu araştırmada fenomonolojik bir yöntem benimsenmiştir. Fenomenoloji, insanların belirli bir fenomen veya kavramla ilgili anlayışlarını, duygularını, bakış açlları ve algılarını ifade etmelerini sağlayan ve bu fenomeni nasıl deneyimlediklerini tanımlamak için kullanılan nitel bir araştırma yöntemidir (Rose vd., 1995, s. 1124). Fenomenoloji çalışması ayrıca, zihinde var olan yapıyı, merkezi kavramı, deneyimlerin nasıl anlamlandırıldığını ve ilişkilerini incelemektedir. (Christensen ve diğerleri, 2014; Johnson ve Christensen, 2008; Patton, 1990). Bu desen derinlemesine ve ayrıntılı bir anlayışa sahip olmayan olgulara odaklanmaktadır ve her katılımcıdan kendi deneyimlerini kendi ifadeleriyle açılaması istenir. Dolayısıyla, bu araştırmada beş-altı yaş (60-72 aylık) grubu çocukların çevrelerinde yer alan canlı ve cansız varlıklara ilişkin algıları tespit edilmeye çalışılmıştır.

\section{Çalışma Grubu}

Nitel araştırmalarda grubunun büyüklüğü; araştırılacak konunun doğası, çalışmanın tasarımı, kapsamı ve verilerin çeşidi göz önünde bulundurularak oluşturulmaktadır. Araştırma sorusu belirlendikten sonra fenomen hakkında fikir verecek katılımcıların popülasyonu ve sayısı belirlenmelidir (Kleiman, 2004, s. 11). Çalışılan konu açık, net ise ve bilgi görüşmelerde kolayca elde edilebiliyorsa daha az katılımcı gerektirmektedir. Bu noktadan hareketle, bu çalışma 2018-2019 Eğitim-Öğretim yılında, Giresun il merkezinde Millî Eğitim Bakanlığı’na bağlı bir Anaokulunda, okul öncesi dönemde eğitim gören 5-6 yaş grubundaki 30 çocuk ile yapılmıştır. Çalışma grubu $15 \mathrm{kız}$ ve 15 erkek çocuktan oluşmaktadır. Yukarıda bahsedildiği gibi çalışma kapsamına ilkokula başlamadan hemen önceki (60-72 aylık) yaş aralığı alınmıştır. Bu dönemin tercih edilmesinin nedeni ilkokulda görülen derslerdeki bu kavrama ilişkin öğrenme alanları ve konu içeriklerinde bu bilgilerle karşılaşacak ve öğrenecek olmalarıdır.

\section{Veri Toplama ve Analizi}

Fenomonolojik çalı̧̧malarda veri oluşturma genellikle derinlemesine ve çoklu görüşmeler kullanılarak yapılmaktadır. Çalışmada incelenen olgular hakkında derinlemesine veri toplamak amacıyla ölçme aracı olarak "varlık kartları” ve görüşme formu kullanılmıştır. Çocukların canlı ve cansız kavramları ile ilgili düşüncelerini belirlemek için kendilerine 12 karttan oluşan ve her bir kartta canlı veya cansız nesnenin bulunduğu (tavşan, köpek, kuş, mantar, çiçek, ağaç, kitap, balon, masa, bulut, bardak, araba) resimler gösterilmiştir. Bu varlıklar seçilirken çocuklara oldukça tanıdık gelen nesneler olması amaçlanmıştır. Çocukların görüşü alınacak nesnelerin her biri çocukların yakın çevrelerine ait, günlük yaşamlarında rast geldikleri canlı ve cansız varlıklar olmalıdır. Hangi sosyokültürel veya sosyoekonomik ortamdan gelirse gelsin, bu yaşta bulunan çocukların geneli bu varlıkları tanımaktadır. Bunlara ek olarak, çocuklara konuyla ilgili 7 madde içeren açık uçlu sorular sorulmuş ve görüşme yapılmıştır. Nitel araştırmada veri ve betimsel analiz; önceden belirlenmiş bir çevreye bağlı olarak nitel verilerin işlenmesi, bulguların tanımlanması, tanımlanan bulguların yorumlanması şeklinde yapılmaktadır. Betimsel analizin, araştırmacılar için çalışmak istedikleri farklı olgu ve olaylar hakkında özet bilgi elde edebilmeleri için sıklıkla başvurulan bir yöntem olduğu belirtilmiştir (Büyüköztürk, Çakmak, Akgün, Karadeniz ve Demirel, 2008). Bu analize tabii tutulan bu çalışmaların seçiminde birtakım ölçütler belirlenmiştir. Betimsel analiz var olan durumu olduğu şekilde ortaya çıkarmayı amaçlamaktadır. Dolayısıyla, çocuklardan gelen görüşler olduğu haliyle yansitılmaktadır.

\section{Geçerlilik ve Güvenirlilik}

Nicel araştırmaların geçerliği ve güvenirliği için farklı ölçme yöntemleri bulunmasına rağmen nitel araştırmalarda kesin bir geçerlik ve güvenirlik tespiti yapmak mümkün olmamaktadır (Baltac1, 2019, s. 380). Ancak doğru bilgiye ulaşma konusunda gereken önlemlerin alınması geçerliğin sağlanmasında ve araştırma sürecinin ve verilerinin açık ve ayrıntılı bir şekilde yani bir başka araştırmacının değerlendirmesine imkân verecek şekilde tanımlanması da güvenirliğin sağlanmasında, nitel araştırmacının karşılaması gereken önemli beklentilerdir (Yıldırım \& Şimşek, 2016, s. 284-285). Nitel çalışmaların geçerliliği sağlaması verilerin ayrıntılı bir tablo ile sunulmasıdır (Yıldırım ve Şimşek, 2016). Bu bağlamda araştırmanın amacı uygun sorulara yanıt alınmaktadır ve bulguların verileri derinlemesine raporlandırılabilmektedir. Araştırmanın geçerliliğini sağlamak adına bir diğer yöntem de çeşitlemedir (Seggie ve 
diğerleri, 2017; Oppermann, 2000; Yıldırım ve Şimşek, 2016). Bu bağlamda derinlemesine bilgi edinilen durum çalışması veri toplama sürecinde önemli yer almaktadır.

Veri toplama araçlarının kapsam geçerliliğini sağlamak için alanda iki akademisyen ve bir okul öncesi öğretmeni olmak üzere üç uzmanın görüşleri alınmıştır. Ayrıca, erken çocukluk dönemi çocuklarının heyecan duyabileceği durumlar göz önünde bulundurularak etki altında kalmayacakları bir ortamda bizzat öğretmen tarafından uygulanarak çocuk ve öğretmen dışında kimsenin bulunmadığı ortamda uygulanmıştır. Çocukların cevapları öğretmenin defterine tamamıyla not edilmiş olup, görüşmeler ses kaydına alınmıştır.

\section{BULGULAR}

Bu çalışma, erken çocukluk dönemindeki beş-altı yaş grubu (60-72 aylık) çocukların canlı ve cansız varlık algılarını incelemek amacıyla yapılmıştır. Beş-altı yaş grubu çocukların canlı ve cansız kavramlara yönelik düşüncelerini belirlemek ve canlı ve cansız nesneler için düşündükleri özellikleri ortaya çıkarmak amaçlanmıştır. Bu esnada, çocuklarda bu özellikler hakkında oluşan kavram yanılgıları ele alınmıştır. Çocuklara yöneltilen sorularla görüşme yapılmış ve 12 maddelik formdan elde edilen veriler tablolar halinde ayrı ayrı incelenmiştir.

\section{0-72 Aylık Çocukların Varlıkları Canlı-Cansız Olarak Tanımlaması}

Çocuklara ilk olarak varlık kartları gösterilmiştir. Kartlar üzerinde gösterilen varlıkların canlı mı yoksa cansız mı olduklarına dair verdikleri cevaplara ait frekans dağılımları Tablo1'de verilmiştir.

Tablo 1. 60-72 aylı çocukların varlıkların canl-cansız olma durumu ile ilgili cevaplarına ilişkin frekans dağılımları

\begin{tabular}{llll} 
Varlık & Canlı & Cansız & Yorumsuz \\
\hline Kuş & 29 & 1 & 0 \\
\hline Tavşan & 27 & 1 & 2 \\
Köpek & 25 & 2 & 3 \\
Balon & 21 & 9 & 0 \\
Çiçek & 13 & 17 & 0 \\
Mantar & 9 & 20 & 1 \\
Ağaç & 9 & 18 & 3 \\
Bulut & 5 & 23 & 2 \\
Araba & 5 & 20 & 5 \\
Kitap & 4 & 24 & 2 \\
Masa & 4 & 26 & 0 \\
Bardak & 0 & 26 & 4
\end{tabular}

Tablo 1 incelendiğinde, çocukların çoğu kuş, tavşan ve köpeği canlı varlıklar olarak yorumlamışken, yine çoğu çocuk balonun canlı olduğunu düşünmüştür. Öte yandan, araba, kitap, masa ve bardak da çocukların çoğunluğu tarafından cansız varlıklar olarak yorumlanmıştır. Bazı varlıklar için ise canlı ya da cansız olduklarına dair yorum yapılamadığı durumlar da tabloda gösterilmiştir. Çocukların Tablo 1'deki varlıklara ilişkin verdikleri cevaplar ışığında Tablo 2`de canlı-cansız varlıkları doğru fark etme sayıları ayrıca gösterilmiştir.

Tablo 2. 60-72 aylık çocukların varlikların canl-cansız olma durumu ile ilgili doğru cevaplarına ilişkin frekans dağıllmları

\begin{tabular}{l|l|lc}
\hline Canlı Varlıkları Bilen Çocuklar & & Cansız Varlıkları Bilen Çocuklar \\
\hline Kuş & 29 & Bardak & 26 \\
Taşan & 27 & Masa & 26 \\
Köpek & 25 & Kitap & 24 \\
Çiçek & 13 & Bulut & 23 \\
Mantar & 10 & Araba & 20 \\
Ağaç & 9 & Balon & 9 \\
\hline
\end{tabular}

Tablo 2'ye göre, çocukların çoğu kuş, tavşan ve köpeğin canlı olduğunu ifade ederken, grubun yaklaşık yarısı çiçek ve mantarın canlı olduğunu düşünmüştür. Ağacın canlı varlık olduğunu düşünen ise azınlıktadır. "Ağaç nasıl canlı 
olsun, öylece duruyor. (Ahmet)" yorumunu yapan çocuk hareketsiz varlığı cansız olarak düşünmüştür. Öte yandan, çocukların çoğu cansız varlıkları doğru nitelendirmiş, ancak balonun cansız olduğunu düşünen azınlıkta kalmıştır. Bu hususta, "balon bir yerden bir yere hareket ediyor, uçabiliyor, o yüzden canlıdır. (Ece)" diyen çocuklardan birinin bu görüşü balonun neden canlı olarak görüldüğünü açıklar niteliktedir. Yani 'hareket etme' canlılıkla ilişkilendirilen bir özellik olarak görülmüştür. Diğer taraftan öğrencilerin canlı - cansız varlıkların kıyaslanmasına ilişkin açık uçlu sorulara verdikleri cevaplar aşağıda sunulmuştur.

\section{0-72 Aylık Çocukların Varlıkların Canlılık Özelliklerine İlişkin Görüşleri}

Bir varlığın, organizma yani canlı sayılabilmesi için bazı özellikleri bulundurması gerekmektedir. Çalışmanın başında belirtildiği gibi günümüzde canlılık özellikleri beslenme, hareket, solunum, özümleme, büyüme, boşaltım, üreme şeklinde tanımlanmaktadır. Araştırma sürecinin diğer bölümünde, çocuklara varlıklar ve bu canlılık özellikleri hakkındaki düşüncelerini ortaya çıkarmak adına açık uçlu sorular sorulmuş ve görüşme yapılmıştır. Çocuklardan gelen yanıtlar ışığında, 60-72 aylık çocukların varlıkların canlı-cansız kıyaslaması ile ilgili verdikleri cevaplara ilişkin frekans dağılımları aşağıdaki tabloda verilmiştir.

Tablo 3. 60-72 aylık çocukların varlkkların canl-cansız kıyaslaması ile ilgili verdikleri cevaplara ilişkin frekans dağılımları

\begin{tabular}{|l|llll|}
\hline Sorular & \multicolumn{3}{|c|}{ f } & f \\
\hline Tavşan mı yoksa masa mı canlıdır? Neden? & Tavşan & 28 & Masa & 2 \\
\hline Balon mu yoksa ağaç mı cansızdır? Neden? & Ağaç & 10 & Balon & 17 \\
\hline Hangisi hareket eder? Kuş mu, kitap mı? & Kuş & 29 & Kitap & 1 \\
\hline Bardak mı yoksa çiçek mi cansızdır? Neden? & Çiçek & 6 & Bardak & 23
\end{tabular}

Tablo 3 incelendiğinde, öğrenciler tavşanın canlı olduğunu söylerken sadece birkaçı masanın canlı olduğunu düşündüğü görülmektedir. Tavşanı canlı olarak düşünen çocukların çoğu 'tavşanın zıplaması, havuç yemesi, koşması, hayvan olması' gibi nedenler belirtmiştir. Masanın canlı olarak seçilmesinin nedenleri ise "masanın sandalyesi vardır, masada yemek yiyebiliyoruz" şeklinde belirtilmiştir. Balon veya ağacın cansız olup olmadığına ilişkin verilen cevaplara bakıldığında, çocuklar ağacın cansız olduğunu düşünürken, birçoğu da balonu cansız olarak düşünmektedir. Çocukların azınlıkta olan grubu ise ikisinin de cansız olduğunu düşünmektedir. Balonu cansız olarak düşünme nedenleri arasında "balonun kendi kendine havalanması, rüzgâr da kendiliğinden uçması, renkli olması" gibi ifadeler yer alırken; ağaca cansız demelerinin başlıca nedenleri "ayaklarının olmaması, kollarının olmaması, sonbaharda yapraklarını dökmesi” şeklinde bulunmuştur.

Diğer yandan, kuş ve kitaptan hangisinin hareket ettiğine dair verilen cevaplara bakıldığında çocukların neredeyse tamamı kuşun hareket ettiğini söylerken, sadece bir çocuk kitabın hareket ettiğini söylemektedir. Kuşun canlı olduğunu gösteren sebepler arasında "gözleri var, uçar, konuşur, yemek yer" ifade edilirken, "kitabı alı okuruz" söylemi kitabın hareket nedeni olarak belirtilmiştir.

Son olarak, bardağın mı yoksa çiçeğin mi cansız olduğu sorusuna, çocuklar çiçek cevabını verirken, çoğunluk bardağın cansız olduğunu düşünmektedir. Sadece bir çocuk her iki varlığın da cansız olduğunu belirtmiştir. Çiçeği cansız seçme nedenleri arasında "ayakları yok, koklamamız gerekiyor, köyde yaşadiğından dolayı koparılır" ifadeleri yer alırken, "yüzü yok, ă̆zı yok, bardak konuşamaz, onda su içeriz, çay içeriz, bıraktığımız yerde durur" gibi sebepler bardağın cansız olduğu ile ilgili gösterilmiştir. Her ikisinin cansız olduğunu söyleyen çocuk ise nedenini "ikisi de cansızdır gözleri ve ağzı yok" şeklinde ifade etmiştir. Öte yandan, yalnızca çiçek kart üzerinde gösterildiğinde çocukların tamamından yarısından fazlası çiçeğin cansız olduğunu, kalan kısmın ise canlı olduğunu düşünmektedir. Çiçeğin canlılık belirtileri için "sallanıyor, rüzgârda hareket etmesinden kaynaklı, çiçekler açarlar, sularız, su içiyor" gibi ifadeler belirtilmiştir.

Devamında, çocuklara diğer bazı varlıkların canlılık özelliklerine ilişkin açık uçlu sorular sorulmuştur. Bu sorularla çocukların; bir arabanın büyüyüp büyümediği ve sebebi, bulutun neden canlı veya cansız olduğu ve köpeğin hangi özelliklerinden dolayı canlı ya da cansız olarak düşündükleri irdelenmeye çalışılmıştır. Çocuklardan gelen yanıtlar incelendiğinde; bazı çocuklar arabanın büyüdüğünü söylerken, çocukların çoğunluğu arabanın büyümediğini dile getirmiştir. Arabanın büyüdüğünü söyleyen çocukların nedenleri arasında "insanlar gibi büyür, yavaş yavaş büyür, büyük olduğu için büyümüş olur" yer alırken, "yemek yemezler, benzin ile çalışılar, büyüyüp gelişmezler, sıradan bir 
araba, bazen büyükleri olur bazen küçükleri olur o yüzden büyümezler, gelişip büyümez çünkü onları bir yerden alırız" gibi nedenler arabanın büyümediğini söyleyen çocuklara aittir.

Bulut ile ilgili verilen cevaplar incelendiğinde, cansız varlık olması frekansının çoğunlukta olduğu ve bunun nedenleri arasında "yağmur yağdırmasl, gökyüzünde olmasl, yüzü olmaması, konuşamaması, yürüyememesi, koşamaması" yer alırken; bazı çocuklar bulutun canlı olduğunu dile getirip ( $\mathrm{f}=8$ ), nedenlerini ise "yağmur yağdığı zaman hareket eder, havada olduğu için canlıdır, havada gezer" şeklinde belirtmişlerdir. Son olarak, çocukların tamamı köpeğin canlı olduğunu söylemişlerdir. Canlılığın başlıca belirtileri için ise "hareket eder ve tepki verir, ısırır, havlar, sahibi olduğumuzu bilir, yavruları vardır" gibi ifadeler yer almaktadır.

Çocukların canlı varlıkları neden canlı gördükleri ve dolayısıyla, canlılık özellikleri hakkındaki görüşlerinin sınandığı sorular ile ilgili bulgular Tablo 5’te sıralanmıştır. Bu noktada çocukların canlı-cansız varlık algısına ilişkin kavram yanılgıları da görülmektedir.

Tablo 4. 60-72 aylık çocukların varlkkların canlılı özellikleri olarak düşündükleri durumlarla ilgili verdikleri cevaplara ilişkin frekans dağılımları

\begin{tabular}{|c|c|c|}
\hline Canlılık Özellikleri & $f$ & $\%$ \\
\hline Hareket & 30 & 100 \\
\hline Tepki verme & 27 & 90.00 \\
\hline Beslenme & 26 & 86.60 \\
\hline Büyüme & 23 & 76.70 \\
\hline Solunum & 3 & 10.00 \\
\hline Üreme & 1 & 3.30 \\
\hline Boşaltım & 0 & 0 \\
\hline Ses verme & 30 & 100 \\
\hline Ziplama & 24 & 80.00 \\
\hline Koşma & 19 & 63.30 \\
\hline Gökyüzünde olma (yüksekte) & 17 & 56.70 \\
\hline Rüzgârda uçma & 14 & 46.70 \\
\hline Yağmur Yağması & 13 & 43.30 \\
\hline Gözlerinin olması & 12 & 40.00 \\
\hline Ondan su içilmesi & 11 & 36.70 \\
\hline Ağzı olması & 6 & 20.00 \\
\hline Çiçeğin Sallanması & 6 & 20.00 \\
\hline Tekerleği olması & 5 & 16.70 \\
\hline Renkli olması & 3 & 10.00 \\
\hline Sulanması & 3 & 10.00 \\
\hline Balonun Patlaması & 2 & 6.60 \\
\hline Tavşanı Allah’ın yaratması & 1 & 3.30 \\
\hline
\end{tabular}

Tablo 5’e göre, tüm çocuklar hareket özelliğini canlılık özelliği olarak düşünmektedirler. Canlılığın en önemli özellikleri olarak hareket olarak belirlenmesi hareket etmeyen nesnelerin cansız olarak nitelendirilmesi gibi kavram yanılgıları belirgin bulgular yer almaktadır (Topsakal, 2009). Bunun yanında çocukların büyük bir çoğunluğu tepki verme ve beslenme özelliklerini canlılık özelliği olarak düşünürken; yalnızca bir çocuktan üreme yanıtı alınmış ve hiçbir çocuktan boşaltım ile ilgili bir cevap alınamamıştır. Bu durumun ülkemizde yapılan benzer bir çalışmayla aynı şekilde algılandığı görülmektedir (Bahar ve diğerleri, 2002). Daha açıklayıcı ve anlaşılır olması açısından çocukların canlılık özelliği konusundaki görüşleri aşağıda Şekil 2’deki görsel formuna dönüştürülerek sunulmuştur. 


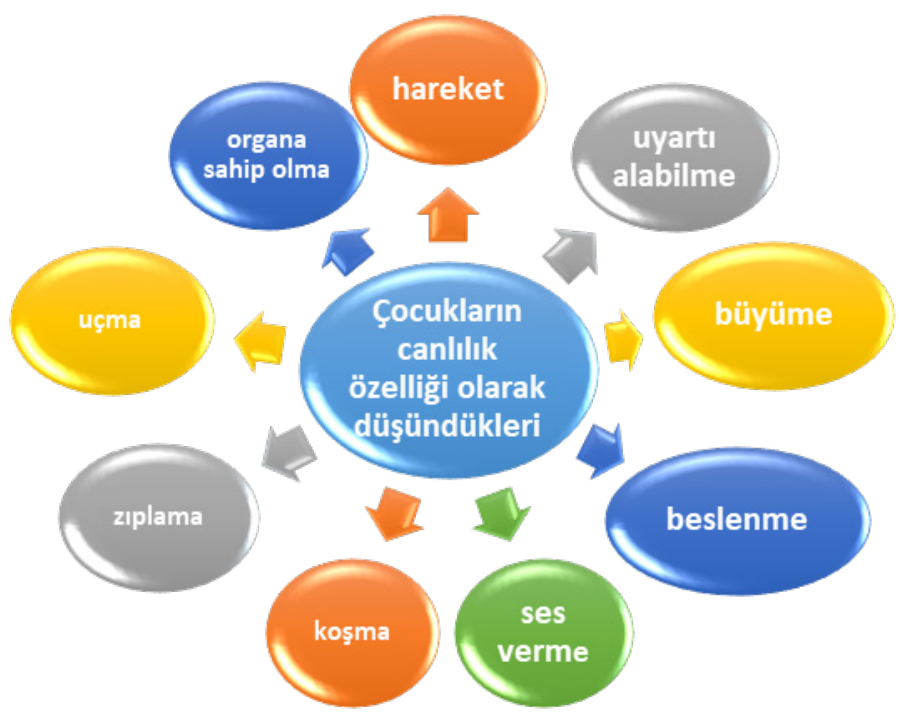

Şekil 2. Çocukların Canlılı Özelliği ile ilgili Düşünceleri

Şekil 2'de, verilen yanıtlar arasında belirlenen canlılık özelliğine ilişkin çocukların düşünceleri gösterilmektedir. Bilimsel yedi temel canlılık özelliğinin dışında ses verme, zıplama, koşma, uçma, organa sahip olma gibi özellikler de canlılık özelliği olarak belirtilmiştir. Elde edilen bulgularda yine canlılı̆̆a ait belirgin özelliklerin hareket etme, konuşma, nefes alma olduğu görülmektedir. Çalışma grubunda yer alan az sayıda çocuk, diğer varlıkların ağzının olması, sallanması, tekerleği olması, renkli olması, sulanması ve ondan su içilmesi gibi durumları canlılık özellikleri kategorisinde değerlendirmiştir. Çocukların bitkiler konusunda meraklı oldukları görülmektedir (Kahraman ve diğerleri, 2015). Ancak çalışmaya dahil olan çocukların bitkilerin canlılıklarına ilişkin tereddüt ve yanılgıları olduğunu gözlemlemektedir.

Araştırma verilerine bakıldığında grubun canlı ve cansız özellikleri bilimsel açıdan tam kavrayamadıkları görülmektedir. Görüşlerden elde edilen verilerde dikkati çeken bir başka husus, çocukların boşaltım işlevini canlılık özelliği olarak tanımlamamış olmasıdır. Yani bir diğer deyişle, erken çocukluk döneminde çocuklar boşaltım işlevini bir canlılık özelliği olarak henüz algılayamamış olabilirler. Bunun nedeninin, bu yaş grubundaki çocukların içinde bulunduğu bilişsel dönem olduğu düşünülmektedir. Örneğin, bir bitkinin kendisi gibi boşaltım yaptığını göremeyen çocuk böyle bir işlevi henüz algılayamamaktır.

\section{TARTIŞMA VE SONUÇ}

Yurt dışında ve Türkiye'de yapılan araştırmalara göre çocukların çevre algılarını etkileyen birçok faktör olduğu ifade edilmektedir. Yaş, ekonomik durum, cinsiyet, eğitim durumu gibi faktörler davranışları ve tutumları etkilemektedir (Taşkın, 2004). Dolayısıyla, bu durumun doğaya ilişkin farkındalıkları etkilediği de düşünülebilir. Bu çalışma, erken çocukluk dönemi beş-altı yaş (60-72 aylık) grubu çocuklarının canlı ve cansız kavramlarını nasıl algıladığını öğrenmek amacıyla yapılmıştır.

Erken çocukluk dönemi çocuklarının çevre algılarının fen eğitimi ile birlikte bilişsel ve duyuşsal alanda gelişimleri görülmektedir. Çocukların olumlu tutum geliştirmesinde 3-6 yaş arası etkinliklerin faktörü yüksektir. Çevre erken çocukluk dönemi için önemli bir faktördür. Yapılan çalışmanın beş-altı yaş grubu çocuklarında algıları canlılık ve cansızlık özellikleri ile sınırlamalarında hareketlilik ve hareketsiz olma özellikleri dikkat çekmesi sebebiyle araştırma birçok nesne ile ele alınmıştır. Bu çalışmaya göre, çocukların canlılık özelliğine ilişkin bazı yanlış kavram ya da eksik bilgiye sahip olduğu görülmektedir. Çocukların bu konuda yaşa bağlı bir gelişim gösterdikleri fakat yanlış kavramlara veya eksik bilgilere de sahip olduğu (örneğin; ağaç ve çiçek konusunda) açıkça belirlenmiştir.

Çalışmanın ilk problemi erken çocukluk dönemi beş altı yaş grubu çocuklarının canlı ve cansız kavramlarını nasıl tanımlamakta olduğu üzerinedir. Elde edilen bulgular ışığında, çalışma grubunda yer alan bazı çocukların canlı-cansız kavramlarını karıştırdıkları (bkz. Tablo 2 ve Tablo 3) görülmektedir. Çocuklar bir varlığın canlı olup olmadığını düşünürken, canlandırdıkları ve ilk akla gelen canlılık belirtisinin hareket ve beslenme özelliği olduğu, 'neden?' sorusuna verilen yanıtlardan anlaşılmaktadır. Çocukların çevrelerindeki varlıklara 'canlı' derken, bu kavrama 
verdikleri anlam farklı olabilmektedir. Örneğin, onlara göre çiçek ve balon canlıdır. Bazı çocuklar çiçek ve balonun canlı olduğunu savunurken, canlıların temel karakteristik özelliklerini (hareket) öne sürmektedirler. 'Balon' ve 'çiçeğin' uçuyor veya sallanıyor olması varlık için canlı sonucuna ulaşmalarına sebep olduğu görülmektedir.

Bu çalışma sonucunda elde edilen bulgular, çocukların okul öncesi dönemde canlı varlıkların kolay fark edilmesinin büyüme, hareket, beslenme özelliklerinden kaynakladığını göstermektedir. Varlıklara göre sorulan kartlarda çocukların hayvanları sınıflandırması daha kolay sağlanmaktayken, bitki üzerinde daha fazla düşündükleri görülmüştür. Bir başka deyişle çocuklar, bu varlıkları sınıflandırmakta zorlanmışlardır. Onlar için cansız varlıkların ve bitkilerin ağzı, gözü, yüzü, ayağı olmadığı için canlı olarak düşünülmemektedir. Stavy ve Wax (1989) çalışmasında bitkilerin canlılık özelliklerinin bilinmesiyle hayvanlara verilen canlılık özelliği aynı şekilde sınıflandırıldığını belirtmektedir. Hayvanları canlı olarak temsil eden tavşanın; hareketli olması, çevrede rahatlıkla görülebilmesi, zıplaması, yemek yemesi gibi özellikler onun canlı olarak seçilmesini sağlamaktadır. Bu noktada, çocukların canlı-cansız varlık bilgilerinde karışıklık olduğu görülmektedir. Çocukların canlı varlıkları kolay seçebilmesinin genel olarak duyu organlarının ve belli varlıkların vücut özelliklerinin olması canlı olarak nitelendirmelerini sağlamaktadır.

Araştırmanın bir diğer alt problemi çocukların yaşadıkları alanda canlı ve cansız varlıkları nasıl ayırt ettiğini sorgulamaktadır. Çalışma grubunda yer alan çocukların verdiği yanıtlara bakıldığında; canlılık özelliklerinde hareketi, büyümeyi, beslenmeyi ve solunumu büyük oranda fark ettiği ancak üremeyi ve boşaltımı fark etmediği görülmektedir. (Bkz. Tablo 6). Bu sonuç daha önceki bazı çalışmalarla benzeşmektedir (Bahar ve diğerleri, 2002; Laurendeau ve Pinard, 1962; Yeşilyurt, 2003; Zogza ve Papamichael, 2000). Bahar ve diğerleri (2002) ve Aksu (2013) çalışmalarında yer alan okul öncesi çocuklarının yarısının güneşin hareket etmesinden dolayı onu canlı olarak kabul ettiğini belirtmiştir. Çocuklar güneşin sabah doğması, akşam batması, etrafa 1sı ve sşık ve 1şık vermesi gibi fiziksel özelliklerini ifade ederek, bu özelliklerinden dolayı güneşi canlı olarak düşünmüştür. Çocuklarda canlılık ve gelişim kavramları araştırmalarda da görüldügü üzere hareket kriterleri üzerine yapılmaktadır. Cansız nesnelere canlılık özelliği kazandırılması "animiz", cansız varlıkları nedensel akıl yürütme olarak analiz edilmektedir. Yorek ve arkadaşları (2009) araştırmasında çocukların hareket kavramını animistik düşünce ile bağdaştırmaktır. Canlı ve cansız varlıkları ayırt etmek için kendilerinin düşündüğü bazı özellikler bulunduğu söylenebilir. Bu özellikler duyu özellikleri ve canlılık özelliklerinde hareket ve büyümeyi ele alsa bile içlerinde, yaratıcı tarafından yaratılmak gibi, farklı örnekler de yer almıştır. Varlığın renkli olması, zıplaması, gözü olması, ağzı olması, rüzgârda uçması, koşması, gökyüzünde olması, patlaması, sulanması, ondan su içilmesi, yağmur yağması, çiçeğin sallanması, tekerleği olması özellikleri çocukların çevrelerinde rastladıkları olaylara dikkat ettikleri ve bu özelliklerin canlı ve cansız ayırt edici özelliği olarak değerlendirdikleri görülmektedir. Örneğin, köpeğin yavruları olduğunu bilen çocuk üreme hakkında fikir üretememektedir.

$\mathrm{Bu}$ çalışmanın son alt probleminde erken çocukluk dönemi beş-altı yaş grubu çocuklarının cansız varlıkları nitelendirmesindeki kavram yanılgıları olduğunu belirlemek amaçlanmıştır. Çocukların canlı olan varlıkları cansız olarak sınıflandırmasında duyu organları olmadığından, gereksinimler için kullanılmasından ve çevrelerinde görülen günlük olaylardan yola çıkılarak özellikle üç varlığa verilen cevapların bitki ve mantar grubu varlıklarına verilen ortak cevap olmasından dolayı cansızlık özelliği olarak düşünmüşlerdir.

Çocukların genel olarak bu kavramlara ait bilginin tam olarak öğrenilememesinden dolayı cevapların okul öncesi çocuğunda netlik kazanmadığı görülmektedir. Bununla birlikte, çocukların ağaç ve çiçeğin rüzgârda hareket etmelerinden dolayı kavram kargaşası yaşadığı ve yanlış bilgilere sahip olduğu göze çarpmaktadır. Çocuklara bu objelerin canlı olup olmadığı sorulduğunda bazı çocukların cevap veremediği, bazılarının ise "sallanıyor canlıdır, rüzgârda hareket ediyor bu yüzden canlıdır” cevaplarını verdikleri görülmüștür. Mantar için ise çoğu çocukların cansız olarak nitelendirmesi "mantar yeniliyor, toprağın altından çıkıyor" cevapları verilmesi dikkat çekicidir.

Çocukların kendilerine kartlar üzerinde gösterilen resimdeki objelerin canlı veya cansız olduğu konusunda tereddüt göstermeleri ve bazen yanlış cevap vermeleri canlı ve cansız kavramının doğru özelliklerle öğrenilmemesinden kaynaklandığı düşünülmektedir. Bir başka deyişle, 'canlılık' kavramı erken çocukluk döneminde yanılgılı ve eksik olarak öğrenilebilmektedir. Bunun yanında, çalışmada ortaya çıkan sonuçlara göre, özellikle çocuklar arasında belirgin bir hareketlilik ve gelişim gösteren hayvanların "canlılığı" daha kolay olarak kavranırken, bitkilerin canlılığı konusunda hareket etmemesi ve gelişimsel farklılıkların gözlemlenmeyişinden ötürü canlı olarak sınıflandırmakta zorluk çekilmiştir (Richards ve Siegler, 1989). Çocukların farklı hareket türleri arasında ayrım yaptığı ve yaşamla ilişkilendirdikleri hareket türlerinin aslında canlılar için tipik olduğu hipotezini inceledi, değişen çocukların farklı hareket türleri arasında ayrım yaptıkları ve nesnelerin yalnızca canlı varlıklara özgü tipik hareket türlerini gösterdiklerinde canlı oldukları sonucuna vardıkları bulundu. Tüm bu sonuçlar ışığında, okul öncesi öğretmenleri 
konulara göre daha detaylı gözlemler yapmak için etkinliklerini artırırsa ve çocuk doğal yaşama daha fazla maruz bırakılırsa bu bilgilerin daha doğru öğrenileceği tahmin edilmektedir.

Erken çocukluk dönemindeki çevre eğitimi genel gelişimden etkilenmektedir. Çevre kavramı bütün unsurları içinde barındırır (Gündüz ve diğerleri, 2017). Çocuktaki çevre algılayışı yetişkine nazaran daha geniş çerçevede yer alır. Bu süreçte en önemli husus çocuğa yaşadığı alanı kendisine ait olduğu ve ortamın bir parçası olduğunu göstermektir (Tombul, 2006). Erken çocukluk dönemi çalışmaları ve ailelerin tutumu ile çevre bilinci şekillenmektedir. Çevre algısının oluşmasıyla birlikte ayırt etme güçlülüğü de azalacaktır. Yapılan çalışmaların anlamlılık kazanması canlı ve cansız nesnelerin ayrımını da ortaya koyacaktır (Gülay ve Ekici, 2010).

Çalışma grubunda yer alan çocukların \%97’si nesnelere odaklı canlı anlayışına sahiptir. Benzer şekilde Taşkın (2004) çocukların; çevrelerinde ağaç, çocuk, çiçek, kuş, vb. nesneleri canlı ve cansız özelliklerini söylediğini fakat bunu hareket özelliklerine yönelik ifade ettiğini belirtmektedir. Ülkemizde yapılan doğa etkinlikleri doğayı parçalar halinde alarak uygulamakta ve sınırlı ölçüde ele almaktadır. Dolayısıyla, doğa bilincini oluşturmaya yeterli görülmemektedir (Çukur ve Özgüner, 2008). Çocuklar öyle gözlem yaparlar ki tıpkı birer bilim insanı gibi keşfederek ve merak duygusuyla bilim insanlarının izlediği yolu kullanırlar. Çünkü çocuklar gördükleri nesnelere dikkat ettiğinde merak eder ve üzerinde göz gezdirmeye başlarlar ve araştırmaya başlarlar. Merak duygusunun yarattığ1 sorular çoğalır. Neden? Niçin? Nasıl?.. Etrafta gördükleri nesnelere dokunarak birçok maddeyi birleştirerek sevdiği sonucu ortaya çıkartmaktan keyif alırlar (Erbaş ve diğerleri, 2002). Değerlendirmeler yaparken çocukların bu yönlerini önemsemek önemlidir. Erken çocukluk dönemi doğaya olan sevgi ve doğa bilinci kazandırılması hususunda kritik bir dönemdir. Deneyimler çocukların farkındalık kazanmaları ile empati ve doğa merakını yönlendirici sevgiyle doğa algılarının gelişmesine yardımcı olacaktır. Güler'in (2009) ifade ettiği gibi doğanın anlamı etkileşim halindeyken öğrenilir. Canlılık ve cansızlık özelliklerinin dikkate alınması doğada keşif halinde öğrenilir. Sınıf içinde ve dışında yapılan okul etkinliklerin bilişsel, duyuşsal ve devinimsel alanda programın içinde yer alması hem öğrenme hem de yaşam alanında deneyimleme firsatı verecektir.

\section{ÖNERILER}

$\mathrm{Bu}$ araştırmadan elde edilen bilgiler ışığında öncelikle okul öncesi öğretmenlerine, fen ve doğa etkinliklerini gerçekleştirmeden önce çocukların konu ile ilgili kavramsal yanılgılarını tespit ederek doğru bilgilerin öğrenilmesi üzerinde durulması önerilmektedir. Çocuklara konu ile ilgili kavramların öğretim sürecinde çevreden somut ve bol örneklere yer vererek günümüzde ki bilgilerle birleştirip aktarılmalıdır. Ayrıca çocuklarla mümkün olduğunca fazla gözlem yaparak, onların doğru bilgi edinmeleri sağlanmalıdır. Gözlem, nesne ile birlikte dokunsal faaliyetler ve merak sonucundaki doğru cevaplar çocuğun kafasında yanılgı bırakmadan canlılığa ilişkin kavramlara olan ilgisini geliştirecektir.

Okul öncesi dönem çocuklarına bitki yapı ve işleyişi yönelik daha fazla etkinlik yapılmalıdır. Etkinlikleri ve deneyleri doğal ortamda daha iyi gözlemledikleri görülmüştür. Örneğin çocuk sonbahar yapraklarını toplamak için bahçeye ç1karılmalı ve yaprağı düşerken görmesi çocukta sonbahar mevsimine olan düşüncesini geliştirmeye yarayacaktır. Canlı $\mathrm{m} ı$ cansız $\mathrm{m} ı$ sorularına yönelik cevapları daha doğru bir şekilde verecektir.

Canlılar ve cansızları anlayabilmek, onların doğal özelliklerini fark edebilmek çocukların ileride yaşayacakları birçok öğrenmelere zemin hazırlayacaktır. Bu bağlamda, akademisyen ve araştırmacılar tarafından, çevre ve doğa eğitim kapsamında canlı ve cansız varlık nedir konusunu içeren daha etkili bir program içeriği hazırlanabilir.

NOT: Bu çalışmanın bir bölümü, yazarlar tarafından Eursian Journal of Educational Research (EJER) Congress 2019'da 25460 numaralı sözlü bildiri olarak sunulmuştur.

\section{KAYNAKÇA}

Aksu S. G. (2013). 5-6 yaş çocuklarının canl-cansız kavramları edinimine duyu temelli eğitim programının etkisi. Yüksek Lisans Tezi, Akdeniz Üniversitesi Eğitim Bilimleri Enstitüsü, Antalya.

Bahar, M., Cihangir S. ve Gözün Ö. (2002). "Okul Öncesi ve İlköğretim Çağındaki Öğrencilerinin Canlı ve Cansız Nesneler ile ilgili Alternatif Düşünce Kalıpları”, V. Ulusal Fen Bilimleri ve Matematik Eğitimi Kongresi, 16-18 Eylül 2002, Ankara.

Baltac1, A. (2019). Nitel Araştırma Süreci: Nitel Bir Araştırma Nasıl Yapılır?, Ahi Evran Üniversitesi Sosyal Bilimler Enstitüü̈ Dergisi, 5(2), 368-388. https://doi.org/10.31592/aeusbed.598299 
Büyüköztürk, Ş., Çakmak, E. K., Akgün, Ö. E., Karadeniz, Ş. ve Demirel, F. (2008). Bilimsel Araştırma Yöntemleri (2. Baskı). Ankara: Pegem Akademi.

Creswell, J. W. (2020). Nitel Araştırma Yöntemleri: Beş Yaklaşıma Göre Nitel Araştırma ve Araştırma Deseni, (Çev. Ed: Bütün, M. \& Demir, S.B.). 5. Baskı, Ankara: Siyasal Kitabevi.

Erbaş, S., Ergül, R., Şimşekli, Y. ve Özdilek, Z. (2002). Okul Öncesi Dönemde Fen Öğretimi. Bursa: Ekin Yayınevi.

Eroğlu, M., Akınc1, H.A., Özcan, G.E. (2003) Zooloji. Karadeniz Technical University Library Catalog, Erişim tarihi: 07.02.2020, https://www.ktu.edu.tr/dosyalar/ormankoruma_86435.pdf.

Christensen, L. B., \& Turner, L.A. (2011). Research Methods, Design, and Analysis. Preson: New York

Çukur, D., ve Özgüner, H. (2008). Kentsel alanda çocuklara doğa bilinci kazandırmada oyun mekânı tasarımının rolü. Süleyman Demirel Üniversitesi Orman Fakültesi Dergisi, 2, 177-187.

Gülay, H., Ekici, G. (2010). MEB Okul Öncesi Eğitim Programı’nın Çevre Eğitimi Açısından Analizi. Türk Fen Eğitimi Dergisi, $7(1), 74-84$.

Güler, T. (2009). Ekoloji temelli bir çevre eğitiminin öğretmenlerin çevre eğitimine karşı görüşlerine etkileri. Eğitim ve Bilim, $34(151), 30-43$.

Gündüz, M., Aktepe, V., Büyükkarcı, A., Taş, M. ve Elbir, B.Ç. (2017). Sınıf öğretmenlerinin doğa ve çevreye yüklediği değerlerin tespit edilmesi, Route Education and Social Science Journal, 4(5), 116 - 126.

Halmatov, M., \& Ekin, S. (2017). An assessment of the contribution of parents to environmental awareness for children in the preschool age of 5-6 years. International Journal of Education, Science and Technology, 3(2), 78-87.

Kahraman, Ö. G., \& Ceylan, Ş. (2015). Bilimi yaratan duygu: Çocukların fen ve doğaya ilişkin konulardaki bilgi ve merakları. Türkiye Sosyal Araştırmalar Dergisi, 19(1), 207-230.

Keliher, V. (1997) Children's perceptions of nature. International Research in Geographical and Environmental Education, 6(3), 240-243, doi:10.1080/10382.046.1997.9965051.

Kesicioğlu, O. S., ve Alisinanoğlu, F. (2009). 60-72 aylık çocukların çevreye karşı tutumlarının çeşitli değişkenler açısından incelenmesi. Ahi Evran Üniversitesi Eğitim Fakültesi Dergisi, 10 (3), 37-48.

Kleiman, S. (2004). Phenomenology: To wonder and search for meanings. Nurse Researcher, 11(4), 7-19. https://doi.org/10.7748/ nr2004.07.11.4.7.c6211.

Kıldan, O. \& Pektaş, M. (2009). Erken çocukluk döneminde fen ve doğa ile ilgili konuların öğretilmesinde okulöncesi öğretmenlerinin görüşlerinin belirlenmesi. Ahi Evran Üniversitesi Kırşehir Eğitim Fakültesi Dergisi (KEFAD), 10(1), $113-127$.

Kılıç Z., Atasoy B., Tertemız N., Şeren M.,ve Ercan L., (2001). Konu Alanı Ders Kitabı İnceleme Kılavuzu, Ankara: Nobel Yayın.

Köşker, N. (2019). Okul öncesi çocuklarında doğa algısı. Abant İzzet Baysal Üniversitesi Eğitim Fakültesi Dergisi, 19 (1), $294-308$.

Laurendeau, M. ve Pinard, A. (1962). Causal thinking in the child: a genetic and experimental approach. New York: International Universities Press.

MEB (2013). Okul öncesi eğitim programı. Ankara: Millı̂ Eğitim Bakanlığı Temel Eğitim Genel Müdürlüğü.

Migliarese, N.L. (2012). Researching the child-nature connection. California State Parks. Erişim tarihi: 11.06.2018, https://www. parks.ca.gov/pages/24914/files

Richards, D. \& Siegler R. (1989). Children's understandings of the attributes of life. Journal of Experimental Child Psychology. 42(1), 1-22. https://doi.org/10.1016/0022-0965(86)90013-5

Rose, P., Beeby, J. \& Parker, D. (1995). Academic rigour in the lived experience of researchers using phenomenological methods in nursing. Journal of Advanced Nursing. 21(6), 1123-1129. https://doi.org/10.1046/j.1365 - 2648.1995.210.61123.x

Stavy, R. \& Wax. N. (1989). Children's Conceptions of Plants as Living Things. Human Development, 1989;32:88-94. doi: $10.1159 / 000276367$

Şahin, F., (2000). Okul Öncesinde Fen Bilgisi Öğretimi ve Aktivite Örnekleri. İstanbul: Ya-Pa Yayınevi.

Taşkın, Ö., (2004). Post-materialism, new environmental paradigm and ecocentric approach: "A qualitative and quantitative study of environmental attitudes of Turkish senior high school students". Doktora Tezi, Indiana University, Bloomington.

Tekindal, M. \& Uğuz Arsu, Ş. (2020). Nitel araştırma yöntemi olarak fenomenolojik yaklaşımın kapsamı ve sürecine yönelik bir derleme. Ufkun Ötesi Bilim Dergisi, 20 (1), 153 - 182.

Tombul, F., (2006). Türkiye'de çevre eğitimine verilen önem. Yayımlanmamış Yüksek Lisans Tezi, Ankara Üniversitesi Sosyal Bilimler Enstitüsü, Ankara. 
Topsakal, Ü. (2009). Tematik öğretimin canlı ve cansız varlıklarla ilgili kavram yanılgılarının giderilmesinde etkililiği. Sakarya Üniversitesi Eğitim Fakültesi Dergisi, (17), 219-234.

Yeşilyurt, S. (2003). Ana sınıfı öğrencilerinin ve ilköğretim birinci sınıf öğrencilerinin canlı ve cansız kavramlarını anlama düzeyleri üzerine bir araştırma. Erzincan Eğitim Fakültesi Dergisi, C. 5 (2), s. 83-96.

Yıldırım, A. \& Şimşek, H. (2016). Sosyal Bilimlerde Nitel Araştırma Yöntemleri (10. baskı). Ankara: Seçkin Yayıncılık.

Yorek, N., Şahin, M. \& Aydın, H. (2009). Are animals 'more alive' than plants? Animistic - anthropocentric construction of life concept. Eurasia Journal of Mathematics, Science and Technology Education, 5(4), 369-378.

Zogza V. \& Papamichael, Y. (2000). The development of the concept of alive by preschoolersthrough a cognitive conflict teaching intervention. European Journal of Psychology of Education, 2, 191-205. 


\title{
A Study on Perception of Life of 60-72-Month-Old Children: What Do Children Think About Living and Non-Living Things?
}

\author{
Elif ÖZTÜRK (iD), Meryem TULUM (iD)
}

\section{Introduction and Purpose}

Interacting with nature at an early age contributes positively to the development of the individual's awareness, commitment, love and development of nature towards the development of ecological responsibilities. Science and nature education thus turns into a pleasant curiosity. At this point, this study was deemed necessary so that children can make sense of, define and interpret the environment in which they live. This study was conducted to examine the development of perceptions of living and non-living things in preschool children between the ages of five and six. Within the scope of this research, the children distinguish between living and non-living concepts as living and nonliving according to their characteristics. From this point of view, the aim of this study is to examine the condition of perceptions of living and non-living things in early childhood of 5-6-year-old children.

\section{Methodology}

The study has been handled with a qualitative approach. For this reason, phenomenology design was used in the research. Therefore, it is tried to determine the facts of living and non-living things in the environment of children in the 5-6 age group. It requires fewer participants if the subject being studied is clear and information can be easily obtained in interviews. From this point of view, this study consists of thirty children in the 5-6 age group, who are educated in the preschool period in a kindergarten affiliated to the Ministry of National Education (MoNE) in the city center of Giresun. The study group consists of 15 girls and 15 boys. As mentioned above, the age range just before starting primary school (60-72 months) was included in the scope of the study. The reason why this period is preferred is that they will encounter and learn this information in the lessons in primary school, learning areas and subject contents related to this concept. "Living and non-living being cards" and "interview form" were used as measurement tools in order to collect in-depth data about the cases examined in the study. In order to determine the opinions of children about the concepts of living and non-living, they were shown pictures consisting of 12 cards and containing live or non-living objects (rabbit, dog, bird, mushroom, flower, tree, book, balloon, table, cloud, glass, car) on each card. In addition to these, open-ended questions containing seven items were asked to the children and interviewed. The data collected within the scope of the study were analyzed descriptively. In addition, it was aimed to determine the thoughts of children on living and non-living concepts and to reveal the features they think of living and nonliving objects. In order to ensure the content validity of the data collection tools, the opinions of three experts, two academicians and one preschool teacher, were taken. In addition, considering the situations that early childhood children may be excited about, it was applied by the teacher in an environment where they will not be affected, and it was applied in an environment where nobody except the child and teacher was present. The answers of the children were completely recorded in the teacher's notebook, and the interviews were recorded.

\section{Results, conclusion and suggestions}

Concerning the concepts of living and non-living, according to which characteristics children distinguish these concepts as living and non-living, and the misconceptions formed in this regard are within the scope of this study. 
According to the findings, the concept of "vitality" can be learned erroneously and incompletely in early childhood. In addition, it has been determined that while children are more easily grasping the vitality of animals that show a significant mobility and development, they have difficulty in classifying them as living things due to the fact that they do not act on the vitality of plants and developmental differences are not observed. At the end of the research, suitable suggestions were made for researchers and educators. The fact that children hesitate about whether the objects in the picture shown on the cards are alive or non-living and sometimes give wrong answers is thought to be due to the fact that the concept of living and non-living is not learned with the correct features. In other words, the concept of 'vitality' can be learned erroneously and incompletely in early childhood. In addition, according to the results obtained, while the "vitality" of animals, which showed a significant mobility and development especially among children, was easier to grasp, it was difficult to classify them as living because the plants did not act on the vitality and developmental differences were not observed. In the light of all these results, it is estimated that this information will be learned more accurately if preschool teachers increase their activities in order to make more detailed observations according to the subjects and if the child is exposed to natural life more. 